\title{
High-Conductance Pathways in Ring-Strained Disilanes by way of Direct $\sigma-S i-S i$ to Au Coordination
}

\author{
Nathaniel T. Kim, ${ }^{\dagger}$ Haixing Li,${ }^{\ddagger}$ Latha Venkataraman, ${ }^{* \dagger}$ and James L. Leighton* ${ }^{\dagger}$ \\ 'Department of Chemistry, Columbia University, New York, NY 10027 \\ ${ }^{\ddagger}$ Department of Applied Physics and Applied Mathematics, Columbia University, \\ New York, NY 10027
}

\section{Supporting Information}

\section{Table of Contents}

I. STM Break-Junction Experimental Procedures

II. Elongation and Compression Experiments

III. Supplemental Figures from Main Text

IV. DFT Calculations for $\mathbf{1}$ and $\mathbf{2}$

V. General Information

VI. Synthetic Procedures and Compound Characterization

VII. References 


\section{STM Break-Junction Experimental Procedures}

We measure the conductance of single molecules bound to gold electrodes using a custom Scanning Tunneling Microscope (STM). We use a $0.25 \mathrm{~mm}$ diameter gold wire (99.998\%, Alfa Aesar) STM tip and a gold-coated (99.999\%, Alfa Aesar) mica substrate. A commercial single-axis piezoelectric positioner (Nano-P15, Mad City Labs) is used to achieve sub-angstrom level control of the tip-substrate distance. The STM is controlled using a custom software in IgorPro (Wavemetrics, Inc.) and operated under ambient conditions at room temperature. The gold substrate is cleaned using UV/Ozone for 15 minutes prior to use. For each measurement, 1000 traces were first collected prior to adding molecular solutions to ensure that the gold was clean. Solutions of the target molecules at $0.1 \mathrm{mM}$ concentration in 1,2,4trichlorobenzene (Alfa Aesar, $>99 \%$ purity) were added to the substrate for molecular conductance measurements. The applied bias was $225 \mathrm{mV}$, and the substrate was displaced at a speed of $\sim 20 \mathrm{~nm} / \mathrm{s}$ for all measurements. The current and voltage data were acquired at $40 \mathrm{kHz}$. For each molecule, we collected over 10,000 traces to create 1D and 2D conductance histograms (Figures 2 and 4 in the manuscript) without data selection. The 1D histograms were created using logarithm bins (100 bins/decade) and the 2D histograms were created by first aligning all traces at a conductance of $0.5 \mathrm{G}_{0}$ and then overlaying all measured traces in a two-dimensional plot. 


\section{Elongation and Compression Experiments}

Conductance switching experiments were carried out by modifying the voltage ramp applied to the piezo as illustrated in Figure S1.

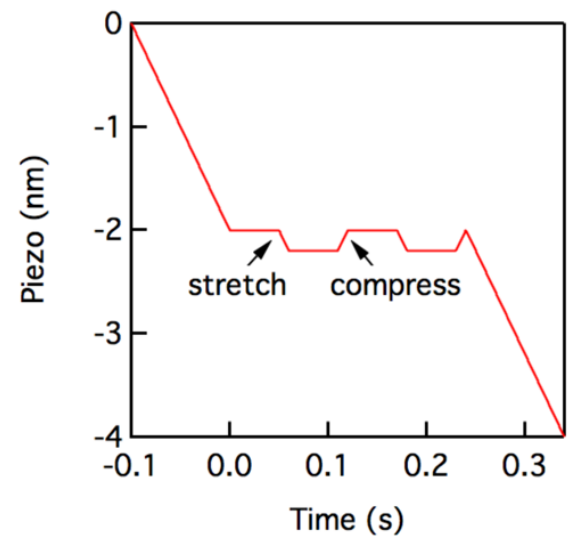

Figure S1. Piezo displacement plotted versus time for the push-pull experiment. We elongate the molecular junction, hold the junction in place for $0.05 \mathrm{~s}$, first stretch the electrodes by either 0.1 or $0.2 \mathrm{~nm}$ hold the junction at this new displacement for another $0.1 \mathrm{~s}$, next compress the electrodes by 0.1 or $0.2 \mathrm{~nm}$ then repeat this one more time and finally retract the electrodes until the junction breaks.

\section{Supplemental Figures from Main Text}

\begin{tabular}{|c|c|c|c|c|}
\hline Molecule & Pull distance & High-to-Low & High-to-High & High-to-break \\
\hline Cis $\mathbf{2}$ & $(0.1 \mathrm{~nm})$ & $29 \%$ & $38 \%$ & $33 \%$ \\
\hline Cis $\mathbf{2}$ & $(0.2 \mathrm{~nm})$ & $35 \%$ & $11 \%$ & $54 \%$ \\
\hline Trans 3 & $(0.2 \mathrm{~nm})$ & $65 \%$ & $26 \%$ & $9 \%$ \\
\hline Cis $\mathbf{4}$ & $(0.2 \mathrm{~nm})$ & $37 \%$ & $23 \%$ & $40 \%$ \\
\hline
\end{tabular}

Table 1. Switching percentages for Molecules 2-4 in the push-pull experiments. 

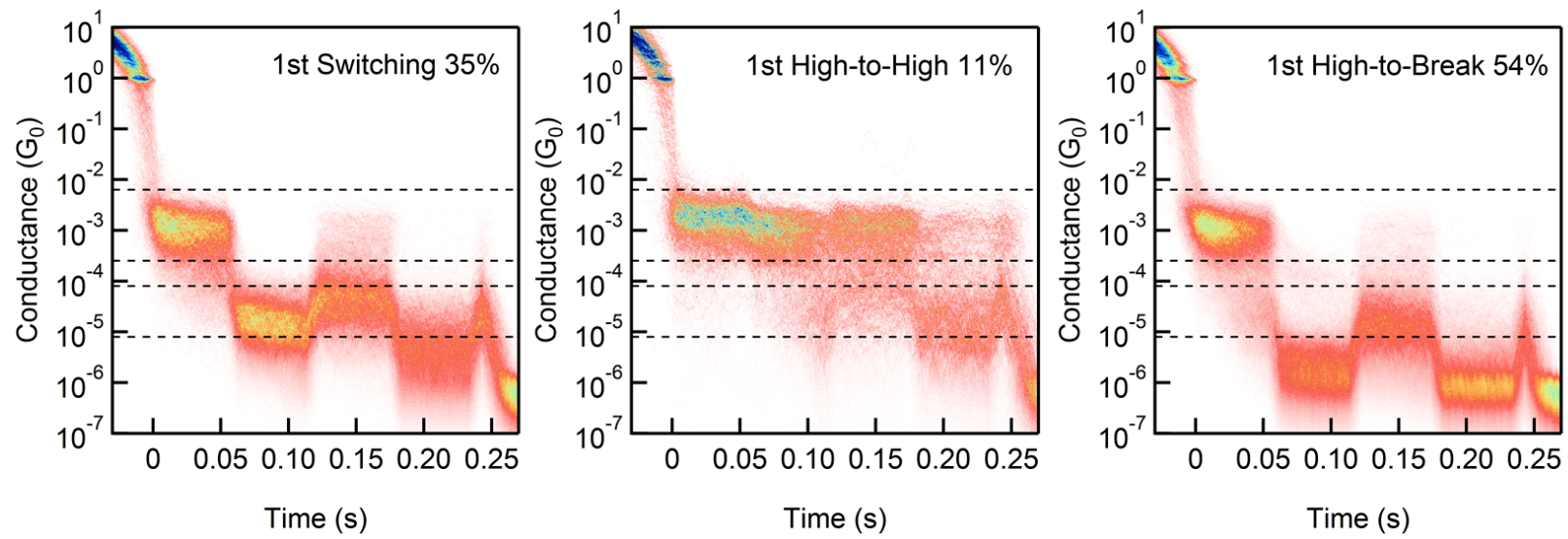

Figure S2. 2D histograms constructed from conductance switching experiments carried out with cis disilane 2 with $0.2 \mathrm{~nm}$ stretch/compress distance. Horizontal dashed lines indicate the high $\mathrm{G}$ and low $\mathrm{G}$ bands. Left: 2D histogram of all traces that show a high $\mathrm{G}$ to low $\mathrm{G}$ switching during the first elongation. Middle: 2D histogram of all traces that show no significant change in conductance after the first elongation. Right: 2D histogram of all traces where the junction breaks after the first elongation.
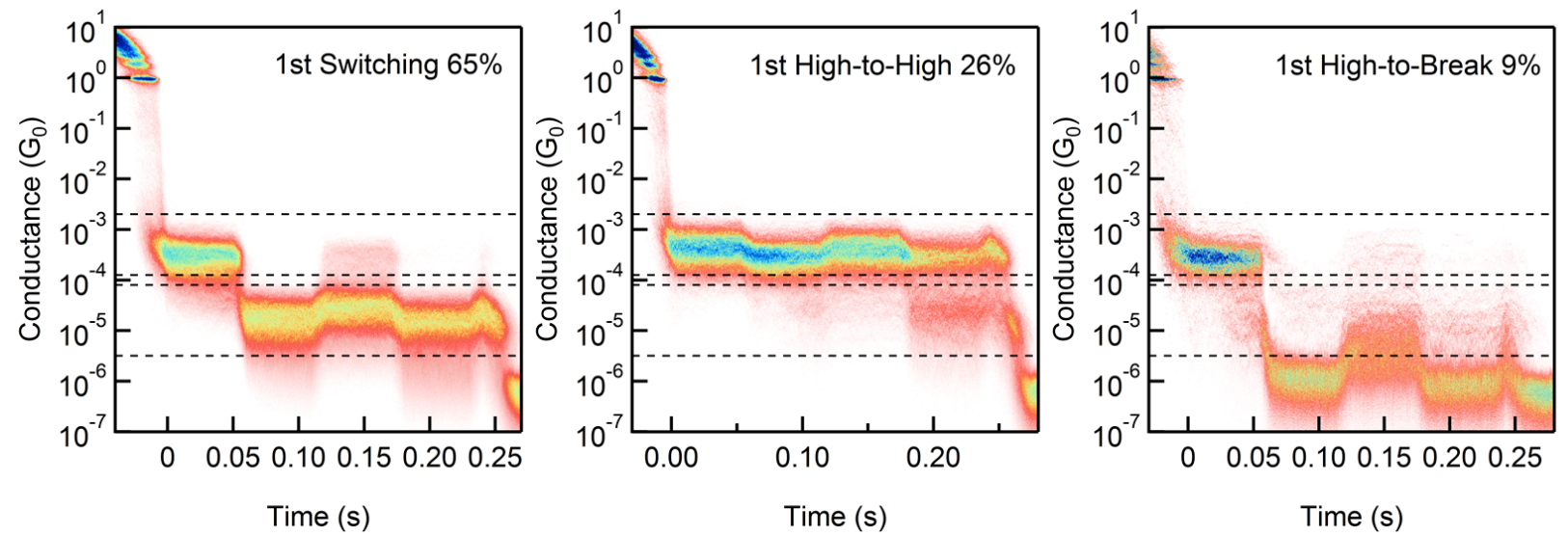

Figure S3. 2D histograms constructed from conductance switching experiments carried out with trans disilane 3 with $0.2 \mathrm{~nm}$ stretch/compress distance. Horizontal dashed lines indicate the high $\mathrm{G}$ and low $\mathrm{G}$ bands. Left: $2 \mathrm{D}$ histogram of all traces that show a high $\mathrm{G}$ to low $\mathrm{G}$ switching during the first elongation. Middle: 2D histogram of all traces that show no significant change in conductance after the first elongation. Right: 2D histogram of all traces where the junction breaks after the first elongation. 

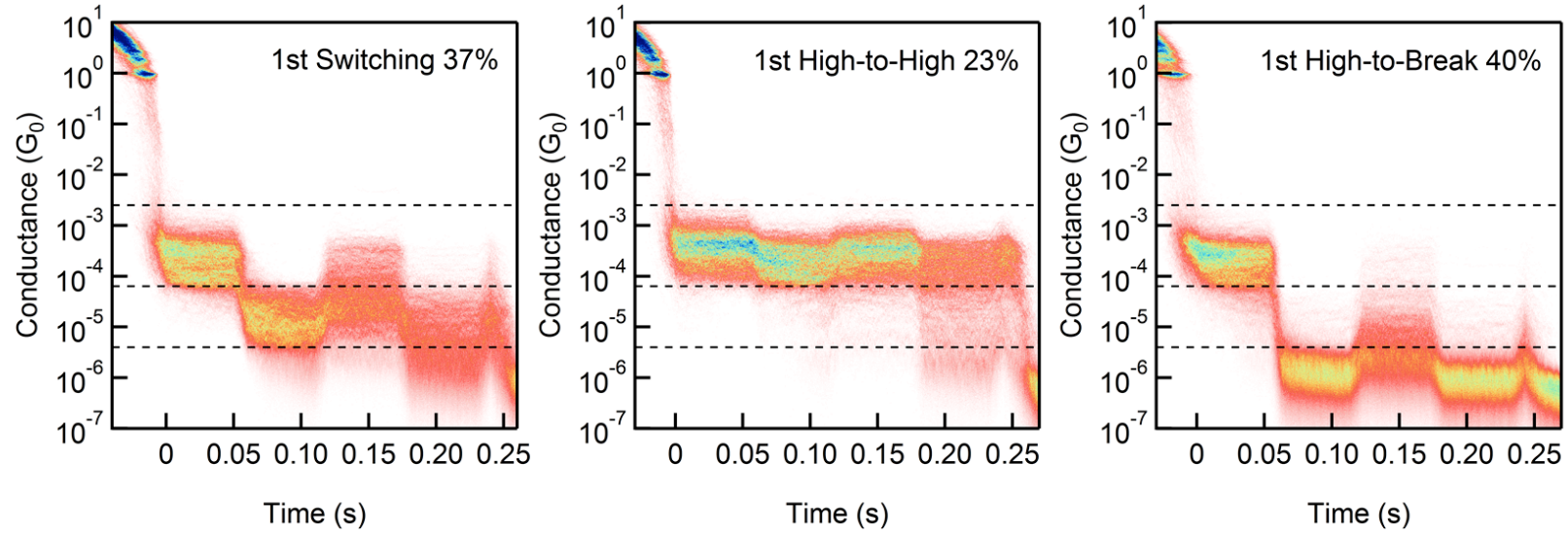

Figure S4. 2D histograms constructed from conductance switching experiments carried out with cis disilane 4 with $0.2 \mathrm{~nm}$ stretch/compress distance. Horizontal dashed lines indicate the high $\mathrm{G}$ and low $\mathrm{G}$ bands. Left: 2D histogram of all traces that show a high $\mathrm{G}$ to low $\mathrm{G}$ switching during the first elongation. Middle: 2D histogram of all traces that show no significant change in conductance after the first elongation. Right: 2D histogram of all traces where the junction breaks after the first elongation.

\section{DFT Calculations for 1 and 2}

DFT calculations were carried out with Jaguar (version 8.6, Schrodinger, LLC, New York, NY, 2014). We used a B3LYP functional for both molecules and a $6-31 \mathrm{G}^{* *}$ basis set for all atoms. No special geometric constraints were applied.

$\underline{\text { Structure Details for trans } 1 \text { from Figure } 1}$

final geometry:

\begin{tabular}{lccc} 
& \multicolumn{3}{c}{ angstroms } \\
atom & $\mathrm{x}$ & $\mathrm{y}$ & $\mathrm{Z}$ \\
$\mathrm{C}$ & 3.87900 & -3.26750 & 1.36860 \\
$\mathrm{C}$ & 3.01440 & -2.16770 & 1.15860 \\
$\mathrm{C}$ & 1.99800 & -2.21230 & 0.21880 \\
$\mathrm{C}$ & 1.81700 & -3.41370 & -0.55300 \\
$\mathrm{C}$ & 2.71200 & -4.51800 & -0.35750 \\
$\mathrm{C}$ & 3.73570 & -4.41290 & 0.62070 \\
$\mathrm{C}$ & 0.75400 & -3.52810 & -1.51670 \\
$\mathrm{C}$ & 0.64440 & -4.69310 & -2.25760 \\
$\mathrm{C}$ & 1.54460 & -5.77010 & -2.08260 \\
$\mathrm{C}$ & 2.54950 & -5.68630 & -1.14720 \\
$\mathrm{Si}$ & 0.84670 & -0.75350 & -0.18520 \\
$\mathrm{Si}$ & -0.46380 & -2.07200 & -1.62440
\end{tabular}




\begin{tabular}{|c|c|c|c|}
\hline $\mathrm{C}$ & -0.00810 & -0.06380 & 1.35750 \\
\hline $\mathrm{C}$ & -0.69290 & -1.45080 & -3.39860 \\
\hline $\mathrm{C}$ & 1.84760 & 0.59780 & -1.05740 \\
\hline $\mathrm{C}$ & -2.12260 & -2.60830 & -0.88390 \\
\hline $\mathrm{C}$ & 3.01850 & 0.28740 & -1.76880 \\
\hline $\mathrm{C}$ & 3.74730 & 1.25750 & -2.45760 \\
\hline $\mathrm{C}$ & 3.32190 & 2.59080 & -2.45520 \\
\hline $\mathrm{C}$ & 2.15500 & 2.92360 & -1.74900 \\
\hline $\mathrm{C}$ & 1.43830 & 1.94510 & -1.06920 \\
\hline $\mathrm{C}$ & -3.33540 & -1.97960 & -1.22450 \\
\hline $\mathrm{C}$ & -4.54180 & -2.34880 & -0.64040 \\
\hline $\mathrm{C}$ & -4.58360 & -3.37110 & 0.32060 \\
\hline $\mathrm{C}$ & -3.39060 & -4.01120 & 0.67400 \\
\hline $\mathrm{C}$ & -2.18830 & -3.63070 & 0.07750 \\
\hline S & 4.16110 & 3.92470 & -3.28860 \\
\hline $\mathrm{C}$ & 5.59220 & 3.10880 & -4.06660 \\
\hline S & -6.18420 & -3.76090 & 1.00370 \\
\hline $\mathrm{C}$ & -5.82790 & -5.08240 & 2.20620 \\
\hline $\mathrm{H}$ & 4.66380 & -3.19890 & 2.11680 \\
\hline $\mathrm{H}$ & 3.16830 & -1.26680 & 1.74840 \\
\hline $\mathrm{H}$ & 4.40630 & -5.25600 & 0.76820 \\
\hline $\mathrm{H}$ & -0.15580 & -4.79880 & -2.98680 \\
\hline $\mathrm{H}$ & 1.43160 & -6.66840 & -2.68330 \\
\hline $\mathrm{H}$ & 3.23480 & -6.51680 & -0.99860 \\
\hline $\mathrm{H}$ & -0.68770 & 0.75780 & 1.10770 \\
\hline $\mathrm{H}$ & -0.60210 & -0.84460 & 1.84220 \\
\hline $\mathrm{H}$ & 0.72040 & 0.31330 & 2.08300 \\
\hline $\mathrm{H}$ & 0.26490 & -1.12150 & -3.81250 \\
\hline $\mathrm{H}$ & -1.37910 & -0.59840 & -3.44060 \\
\hline $\mathrm{H}$ & -1.09510 & -2.23620 & -4.04730 \\
\hline $\mathrm{H}$ & 3.38380 & -0.73640 & -1.78260 \\
\hline $\mathrm{H}$ & 4.64570 & 0.96100 & -2.98710 \\
\hline $\mathrm{H}$ & 1.81030 & 3.95420 & -1.73220 \\
\hline $\mathrm{H}$ & 0.54110 & 2.24610 & -0.53340 \\
\hline $\mathrm{H}$ & -3.34680 & -1.18360 & -1.96550 \\
\hline $\mathrm{H}$ & -5.45930 & -1.84330 & -0.93010 \\
\hline $\mathrm{H}$ & -3.38350 & -4.80930 & 1.40790 \\
\hline $\mathrm{H}$ & -1.28170 & -4.15590 & 0.36730 \\
\hline $\mathrm{H}$ & 6.13220 & 3.90040 & -4.59020 \\
\hline $\mathrm{H}$ & 6.25410 & 2.66260 & -3.32080 \\
\hline $\mathrm{H}$ & 5.27870 & 2.35470 & -4.79200 \\
\hline $\mathrm{H}$ & -6.79050 & -5.33980 & 2.65290 \\
\hline $\mathrm{H}$ & -5.41650 & -5.96900 & 1.71880 \\
\hline $\mathrm{H}$ & -5.15340 & -4.73750 & 2.99320 \\
\hline
\end{tabular}

$\underline{\text { Structure Details for cis } 2 \text { from Figure } 1}$ 
final geometry:

$\begin{array}{lrcc} & & \text { angstroms } & \\ \text { atom } & \mathrm{x} & \mathrm{y} & \mathrm{z} \\ \mathrm{C} & 4.81430 & -0.89530 & 1.51140 \\ \mathrm{C} & 4.17930 & 0.10340 & 0.75530 \\ \mathrm{C} & 2.78320 & 0.10210 & 0.55830 \\ \mathrm{C} & 2.03100 & -0.94920 & 1.14860 \\ \mathrm{C} & 2.65580 & -1.97190 & 1.91290 \\ \mathrm{C} & 4.05240 & -1.92530 & 2.08430 \\ \mathrm{C} & 0.62660 & -0.93680 & 0.93390 \\ \mathrm{C} & -0.13620 & -1.97950 & 1.49920 \\ \mathrm{C} & 0.46290 & -2.99980 & 2.25490 \\ \mathrm{C} & 1.85110 & -2.99110 & 2.45910 \\ \mathrm{Si} & 1.90490 & 1.39450 & -0.48090 \\ \mathrm{Si} & -0.14310 & 0.44160 & -0.07820 \\ \mathrm{C} & 2.34570 & 1.23580 & -2.31800 \\ \mathrm{C} & -0.92920 & -0.19970 & -1.67970 \\ \mathrm{C} & 2.02460 & 3.17950 & 0.12350 \\ \mathrm{C} & -1.29430 & 1.57240 & 0.89230 \\ \mathrm{C} & 2.76770 & 3.53450 & 1.27160 \\ \mathrm{C} & 2.84130 & 4.87870 & 1.68880 \\ \mathrm{C} & 2.17080 & 5.88160 & 0.96000 \\ \mathrm{C} & 1.42000 & 5.53430 & -0.17730 \\ \mathrm{C} & 1.35170 & 4.19120 & -0.59370 \\ \mathrm{C} & -1.45570 & 1.41620 & 2.28550 \\ \mathrm{C} & -2.30590 & 2.27590 & 3.00900 \\ \mathrm{C} & -3.00120 & 3.30290 & 2.34020 \\ \mathrm{C} & -2.83890 & 3.47090 & 0.95270 \\ \mathrm{C} & -1.99220 & 2.60590 & 0.23260 \\ \mathrm{~S} & 2.25050 & 7.57760 & 1.44740 \\ \mathrm{C} & 3.81450 & 7.81070 & 2.33450 \\ \mathrm{~S} & -4.07080 & 4.39360 & 3.22250 \\ \mathrm{C} & -4.99080 & 3.36590 & 4.39870 \\ \mathrm{H} & 5.88590 & -0.87550 & 1.64600 \\ \mathrm{H} & 4.77460 & 0.88660 & 0.30780 \\ \mathrm{H} & 4.54860 & -2.69350 & 2.65900 \\ \mathrm{H} & -1.20610 & -1.99310 & 1.34530 \\ \mathrm{H} & -0.14220 & -3.78970 & 2.67620 \\ \mathrm{H} & 2.30520 & -3.78050 & 3.03920 \\ \mathrm{H} & 1.67560 & 1.82700 & -2.94080 \\ \mathrm{H} & 2.27020 & 0.20020 & -2.64730 \\ \mathrm{H} & 3.36340 & 1.57130 & -2.51130 \\ \mathrm{H} & -0.24420 & -0.86120 & -2.20870 \\ \mathrm{H} & -1.18110 & 0.61830 & -2.35260 \\ \mathrm{H} & -1.84190 & -0.76000 & -1.48020\end{array}$




$\begin{array}{lrrr}\mathrm{H} & 3.28690 & 2.78280 & 1.84860 \\ \mathrm{H} & 3.40740 & 5.12510 & 2.57310 \\ \mathrm{H} & 0.90010 & 6.30120 & -0.73280 \\ \mathrm{H} & 0.77710 & 3.93900 & -1.47300 \\ \mathrm{H} & -0.91840 & 0.63610 & 2.80650 \\ \mathrm{H} & -2.40850 & 2.14900 & 4.07590 \\ \mathrm{H} & -3.36740 & 4.26260 & 0.44170 \\ \mathrm{H} & -1.87640 & 2.74200 & -0.83290 \\ \mathrm{H} & 3.97540 & 8.87120 & 2.52800 \\ \mathrm{H} & 3.79940 & 7.28900 & 3.29130 \\ \mathrm{H} & 4.64900 & 7.43810 & 1.74060 \\ \mathrm{H} & -5.74020 & 3.96720 & 4.91330 \\ \mathrm{H} & -5.49900 & 2.55610 & 3.87510 \\ \mathrm{H} & -4.32500 & 2.93740 & 5.14690\end{array}$

\section{General Information}

All reactions were carried out in flame-dried glassware with magnetic stirring unless otherwise indicated. The flasks were fitted with rubber septa and reactions were conducted under a positive pressure of nitrogen unless otherwise noted. Degassed solvents were purified by passage through an activated alumina column.

Materials. Commercial reagents were used without further purification unless otherwise noted. All reagents were purchased from Sigma-Aldrich, with the following exceptions. 1,1,2,2tetrachlorodisilane was purchased from TCI. 1,8-dibromonaphthalene was purchased from Ark Pharm, Inc.

Instrumentation. ${ }^{1} \mathrm{H},{ }^{13} \mathrm{C}$, and ${ }^{29} \mathrm{Si}$ NMR spectra were recorded on a Bruker DPX-400 (400 MHz) or a Bruker DPX-500 (500 MHz) spectrometer. Chemical shifts for protons are reported in parts per million downfield from tetramethylsilane and are referenced to residual protium in the NMR solvent $\left(\mathrm{CDCl}_{3}=7.26 \mathrm{ppm}\right)$. Chemical shifts for carbon are reported in parts per million downfield from $\mathrm{CDCl}_{3}$ internal standard $(77.23 \mathrm{ppm})$. Chemical shifts for silicon are reported in parts per million downfield from tetramethylsilane and referenced to the silicon resonance of tetramethylsilane (TMS $\delta$ 0.0). The silicon NMR resonances were determined with a DEPT pulse sequence. Data are based on apparent multiplicities and are reported as follows: chemical shift, multiplicity $(\mathrm{s}=$ singlet, $\mathrm{d}=$ doublet, $\mathrm{dd}=$ doublet of doublets, $\mathrm{t}=$ triplet, $\mathrm{m}=$ multiplet), coupling constants in Hertz, and integration. The mass 
spectroscopic data were obtained at the Columbia University mass spectrometry facility using a Waters XEVO G2XS QToF mass spectrometer with a UPC2 SFC inlet, electrospray ionization (ESI) probe, atmospheric pressure chemical ionization (APCI) probe, and atmospheric solids analysis probe (ASAP). Infrared spectra were recorded on a Perkin Elmer Paragon 1000 FT-IR spectrometer. HPLC analyses were performed on san Agilent 1200 Series HPLC, UV detection monitored at $280 \mathrm{~nm}$, using a Luna silica column (3 $\AA$ ) or a Chiralcel IB-3 column $(25 \mathrm{~cm})$.

\section{Synthetic Procedures and Compound Characterization}

Synthesis of trans and cis bisthioanisole substituted 1,2-disilaacenaphthenes 1 and $\mathbf{2}$ :<smiles>Brc1cccc2cccc(Br)c12</smiles>

1. $\mathrm{Si}_{2} \mathrm{Cl}_{4} \mathrm{Me}_{2}, n$-BuLi THF, $0^{\circ} \mathrm{C}$

2.

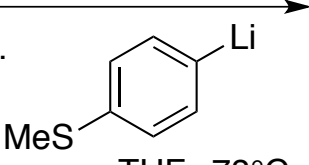

$\mathrm{THF},-78^{\circ} \mathrm{C}$

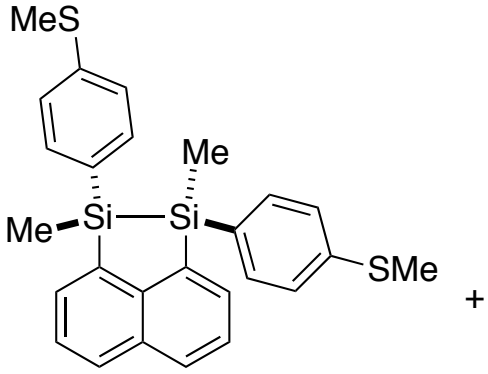

1 trans

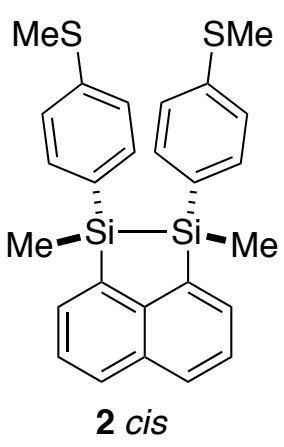

The synthesis of $\mathbf{1}$ and $\mathbf{2}$ was adapted from Wakahara et al. ${ }^{1}$ To a cooled $\left(0{ }^{\circ} \mathrm{C}\right)$ solution of dibromonaphthalene $(1.00 \mathrm{~g}, 3.50 \mathrm{mmol})$ in THF $(17 \mathrm{~mL})$ was added $n$-butyllithium $(2.94 \mathrm{~mL}$, $2.5 \mathrm{M}$ in THF, $7.34 \mathrm{mmol})$. After $10 \mathrm{~min}$, the dilithiate was added by cannula into a cooled (-78 $\left.{ }^{\circ} \mathrm{C}\right)$ solution of 1,1,2,2-tetrachlorodimethyldisilane $(628 \mu \mathrm{L}, 3.50 \mathrm{mmol})$ in THF $(70 \mathrm{~mL})$. The reaction mixture was allowed to warm to room temperature over $1 \mathrm{~h}$ and then cooled $\left(-78{ }^{\circ} \mathrm{C}\right)$. To a separate cooled $\left(-78{ }^{\circ} \mathrm{C}\right)$ solution of 4-bromothioanisole $(1.49 \mathrm{~g}, 7.34 \mathrm{mmol})$ in THF (70 $\mathrm{mL}$ ) was added $n$-butyllithium $(2.94 \mathrm{~mL}, 2.5 \mathrm{M}$ in THF, $7.34 \mathrm{mmol})$. After 1 hour, the thioanisole lithiate was added by cannula into the cooled solution of naphthyl dichlorodisilane. The reaction mixture was warmed to room temperature over 4 hours and quenched by the addition of saturated aqueous $\mathrm{NH}_{4} \mathrm{Cl}(40 \mathrm{~mL})$. The layers were separated and the aqueous layer was extracted with EtOAc $(3 \times 30 \mathrm{~mL})$. The combined organic layers were washed with brine, dried $\left(\mathrm{Na}_{2} \mathrm{SO}_{4}\right)$, filtered, and concentrated. Purification of the residue by silica gel flash chromatography (1\% to $2 \%$ EtOAc/hexanes) afforded trans and cis bisthioanisole substituted 
1,2-disilaacenaphthenes 1 and 2 as a 1.5:1 mixture of trans/cis isomers $(771 \mathrm{mg}, 1.68 \mathrm{mmol}$, $48 \%$ ). Isolated samples of 1 and 2 were obtained by HPLC separation using a Luna silica column (3 $)$.

The assignment of stereochemistry for $\mathbf{1}$ and $\mathbf{2}$ was made as follows: the trans/cis mixture was analyzed by HPLC using a Chiralcel IB-3 column $(25 \mathrm{~cm})$. The chromatogram showed three peaks, two of which integrated in a 50:50 ratio. Compound 1 (the first to elute off of the Luna silica column) was then analyzed using this chiral HPLC assay and showed the two peaks in a 50:50 ratio. Compound 1 is therefore assigned as the trans diastereomer, which is chiral $(d l)$. Analysis of compound 2 using the same chiral HPLC assay revealed a single peak, and this allowed the assignment of $\mathbf{2}$ as the cis diastereomer, which is achiral (meso). The HPLC chromatograms are provided below.

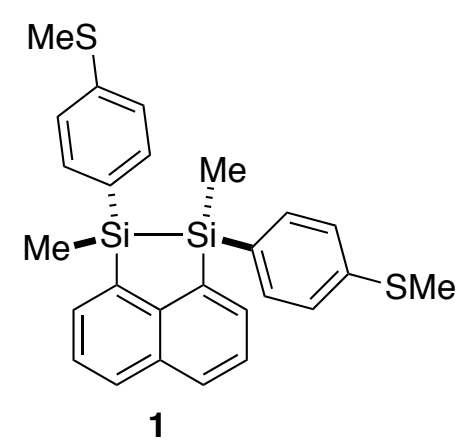

White solid. IR (thin film) 3028, 3003, 2970, 2952, 2920, 2853, $1578,1483,1437,1366,1228,1217,1079,876,791,764,686,527$, $496 \mathrm{~cm}^{-1}$; H NMR (400 MHz, $\left.\mathrm{CDCl}_{3}\right) \delta 7.94(\mathrm{dd}, J=8.3,1.2 \mathrm{~Hz}$, $2 \mathrm{H}), \delta 7.76(\mathrm{dd}, J=6.6,1.3 \mathrm{~Hz}, 2 \mathrm{H}), \delta 7.54(\mathrm{dd}, J=8.2,6.7 \mathrm{~Hz}$, 2H), $\delta 7.34(\mathrm{~d}, J=8.3 \mathrm{~Hz}, 2 \mathrm{H}), \delta 7.19(\mathrm{~d}, J=8.3 \mathrm{~Hz}, 2 \mathrm{H}), \delta 2.46$ $(\mathrm{s}, 6 \mathrm{H}), \delta 0.60(\mathrm{~s}, 6 \mathrm{H}) ;{ }^{13} \mathrm{C} \mathrm{NMR}\left(126 \mathrm{MHz}, \mathrm{CDCl}_{3}\right) \delta$ 147.0, $141.0,139.8,135.1,133.1,132.8,132.3,129.5,126.1,125.7,15.3,-5.0 ;{ }^{29} \mathrm{Si}\left(60 \mathrm{MHz}, \mathrm{CDCl}_{3}\right) \delta$ -22.8. HRMS predicted for $\mathrm{C}_{26} \mathrm{H}_{26} \mathrm{Si}_{2} \mathrm{~S}_{2}$ (ASAP+): calcd 458.1014 ([M] $]^{+}$), observed 458.1019 $\left([\mathrm{M}]^{+}\right)$.

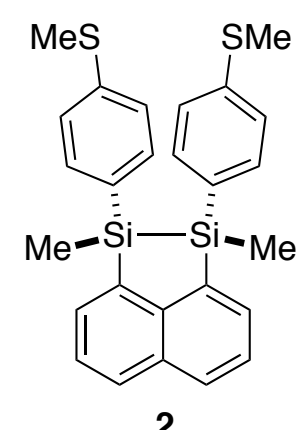

2

White solid. IR (thin film) 3043, 2954, 2921, 2854, 1579, 1485, 1437, 1385, 1254, 1078, 994, 889, 792, 754, 652, 535, $497 \mathrm{~cm}^{-1}$; ${ }^{1} \mathrm{H}$ NMR $(400 \mathrm{MHz}$, $\left.\mathrm{CDCl}_{3}\right) \delta 7.93(\mathrm{dd}, J=8.2,1.2 \mathrm{~Hz}, 2 \mathrm{H}), \delta 7.75(\mathrm{dd}, J=6.7,1.3 \mathrm{~Hz}, 2 \mathrm{H}), \delta$ $7.54(\mathrm{dd}, J=8.2,6.7 \mathrm{~Hz}, 2 \mathrm{H}), \delta 7.22(\mathrm{~d}, J=8.2 \mathrm{~Hz}, 2 \mathrm{H}), \delta 7.06(\mathrm{~d}, J=8.2 \mathrm{~Hz}$, $2 \mathrm{H}), \delta 2.42(\mathrm{~s}, 6 \mathrm{H}), \delta 0.74(\mathrm{~s}, 6 \mathrm{H}) ;{ }^{13} \mathrm{C} \mathrm{NMR}\left(126 \mathrm{MHz}, \mathrm{CDCl}_{3}\right) \delta 146.6$, $141.1,139.7,135.2,133.1,132.7,131.7,129.5,126.0,125.5,15.3,-4.6 ;{ }^{29} \mathrm{Si}$

NMR (60MHz, $\left.\mathrm{CDCl}_{3}\right) \delta$-23.2. HRMS predicted for $\mathrm{C}_{26} \mathrm{H}_{26} \mathrm{Si}_{2} \mathrm{~S}_{2}(\mathrm{ASAP}+)$ : calcd $458.1014\left([\mathrm{M}]^{+}\right)$, observed $458.1009\left([\mathrm{M}]^{+}\right)$. 
Synthesis of trans and cis disilaacenaphthenes $\mathbf{3}$ and $\mathbf{4}$ :

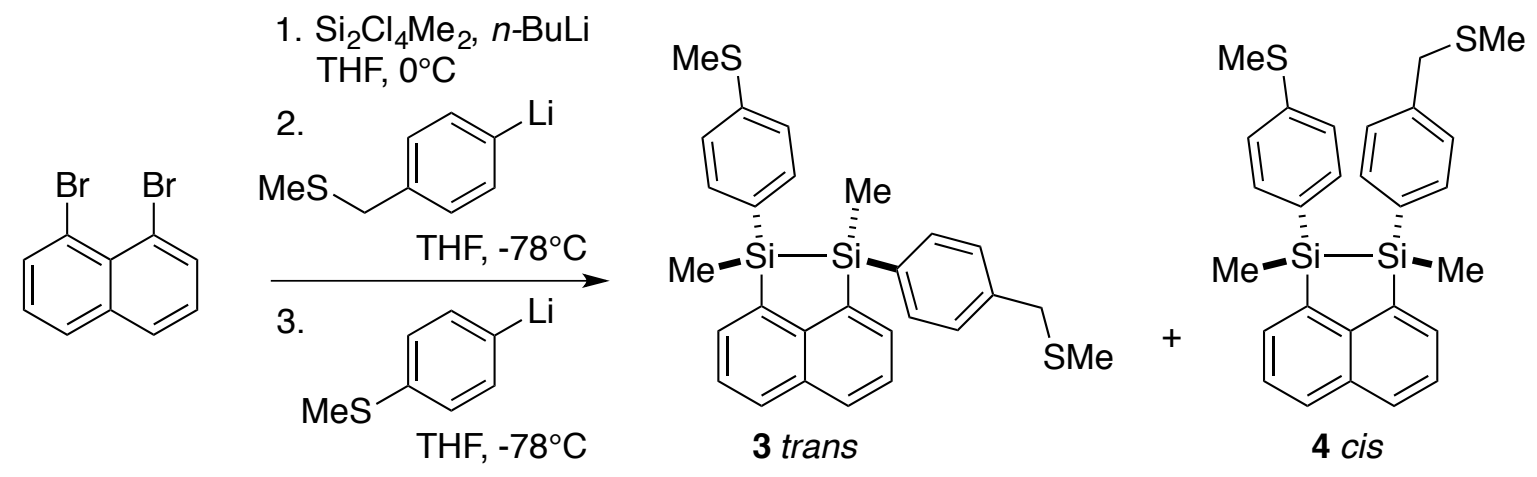

To a cooled $\left(0^{\circ} \mathrm{C}\right)$ solution of dibromonaphthalene $(600 \mathrm{mg}, 2.01 \mathrm{mmol})$ in THF $(10 \mathrm{~mL})$ was added $n$-butyllithium (1.68 mL, $2.5 \mathrm{M}$ in THF, $4.20 \mathrm{mmol})$. After $10 \mathrm{~min}$, the dilithiate was added by cannula into a cooled $\left(-78^{\circ} \mathrm{C}\right)$ solution of 1,1,2,2-tetrachlorodimethyldisilane (378 $\mu \mathrm{L}$, $2.10 \mathrm{mmol})$ in THF $(42 \mathrm{~mL})$. The reaction mixture was allowed to warm to room temperature over $1 \mathrm{~h}$ and then cooled $\left(-78{ }^{\circ} \mathrm{C}\right)$. To a separate cooled $\left(-78{ }^{\circ} \mathrm{C}\right)$ solution of (4bromobenzyl)(methyl)sulfane $(731 \mathrm{mg}, 3.36 \mathrm{mmol})$ in THF $(34 \mathrm{~mL})$ was added $n$-butyllithium (2.94 mL, $2.5 \mathrm{M}$ in THF, $7.34 \mathrm{mmol}$ ). After 1 hour, the benzylmethylsulfide lithiate was added by cannula into the cooled solution of naphthyl dichlorodisilane. The reaction mixture was stirred at $-78{ }^{\circ} \mathrm{C}$ for 4 hours. To a separate cooled $\left(-78{ }^{\circ} \mathrm{C}\right)$ solution of 4-bromothioanisole (256 $\mathrm{mg}, 1.26 \mathrm{mmol})$ in THF (13 mL) was added $n$-butyllithium (504 $\mu \mathrm{L}, 2.5 \mathrm{M}$ in THF, $1.26 \mathrm{mmol}$ ). After 1 hour, the thioanisole lithiate was added by cannula into the cooled solution of naphthyl arylchlorodisilane. The reaction mixture was warmed to room temperature over 4 hours and quenched by the addition of saturated aqueous $\mathrm{NH}_{4} \mathrm{Cl}(30 \mathrm{~mL})$. The layers were separated and the aqueous layer was extracted with EtOAc $(3 \times 20 \mathrm{~mL})$. The combined organic layers were washed with brine, dried $\left(\mathrm{Na}_{2} \mathrm{SO}_{4}\right)$, filtered, and concentrated. Purification of the residue by silica gel flash chromatography (1\% to $2 \%$ EtOAc/hexanes) afforded trans and cis disilaacenaphthenes 3 and $\mathbf{4}$ as a 2:1 mixture of trans/cis isomers (404 mg, $0.854 \mathrm{mmol}, 34 \%$ ). The trans/cis isomeric mixture was separated by analytical HPLC using a Luna silica column (3 $\AA)$ to isolate trans isomer 3 and cis isomer 4. HPLC conditions and traces are included below.

The assignment of stereochemistry for $\mathbf{3}$ and $\mathbf{4}$ was made as follows (we have been unable to obtain crystals of either $\mathbf{3}$ or $\mathbf{4}$, and the chemical shifts of the Si-Me groups do not 
resolve enough to allow a determination using nOe (NOESY) experiments): our assertion that 3 is trans and $\mathbf{4}$ is cis is based on 3 distinct pieces of evidence that together constitute a convincing case. First, the displacement values for the low $G$ sulfur to sulfur pathways shown in Figure 4 are $\sim 0.8 \mathrm{~nm}$ and $\sim 0.6 \mathrm{~nm}$, respectively. The distance between the sulfurs is significantly greater in the trans isomer, and therefore the one with the longer displacement must be the trans isomer. Past measurements have demonstrated that junction elongation lengths determined from 2D histograms correlate strongly with the molecular backbone length, ${ }^{2}$ and we note that this has been proven to be the case for $\mathbf{1}$ and $\mathbf{2}$, where the stereochemistry has been rigorously established and the trans isomer clearly shows a longer displacement value for the low $G$ conductance band (Figure 2). Second, inspection of the ${ }^{1} \mathrm{H}$ NMR data for 2 shows that the $\mathrm{SiC}_{6} \mathbf{H}_{4} \mathrm{SMe}$ protons are all upfield of the $\mathrm{CHCl}_{3}$ peak at $7.26 \mathrm{ppm}$, whereas for $\mathbf{1}$ they are not. The ${ }^{1} \mathrm{H}$ NMR spectra for 3 and $\mathbf{4}$ show exactly the same pattern, again consistent with the assignment of $\mathbf{3}$ as trans and $\mathbf{4}$ as cis. A similar analysis of the $\mathrm{Si}-\mathrm{CH}_{3}$ peaks shows a similar trend with those for $\mathbf{1}$ and $\mathbf{3}$ having a chemical shift of $\sim 0.6 \mathrm{ppm}$, and those for 2 and 4 having a chemical shift of $\sim 0.75 \mathrm{ppm}$. Third, as shown below in the HPLC chromatograms, trans diastereomer 1 elutes off of the Luna silica column first, followed by the cis isomer $\mathbf{2}$. For compounds 3 and $\mathbf{4 , 3}$ elutes first followed by $\mathbf{4}$, further supporting the assignment of $\mathbf{3}$ as trans and $\mathbf{4}$ as cis. We conclude that the chances that all three of these distinct pieces of evidence are reversed are vanishingly small, and that we have established the stereochemistry of $\mathbf{3}$ as trans, and that of $\mathbf{4}$ as cis.

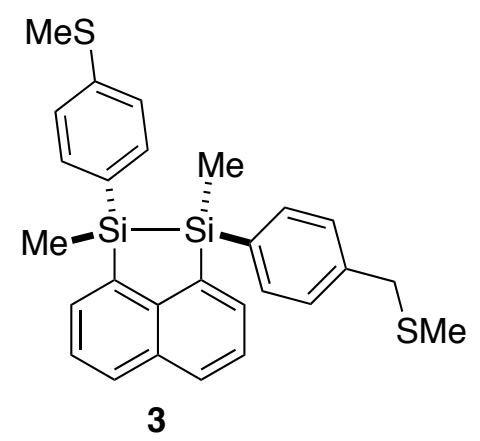

Clear oil. IR (thin film) 3044, 3031, 3008, 2955, 2919, 2852, 1577,
1483, 1436, 1427, 1392, 1384, 1318, 1308, 1247, 1153, 1100,
1078, 1015, 876, 790, 764, 744, 722, 689, 627, 560, 507, 497, 436
$\mathrm{~cm}^{-1}$; ${ }^{1} \mathrm{H}$ NMR $\left(500 \mathrm{MHz}, \mathrm{CDCl}_{3}\right) \delta 7.96(\mathrm{dd}, J=8.2,1.2 \mathrm{~Hz}, 2 \mathrm{H})$,
$\delta 7.79(\mathrm{dd}, J=6.9,1.2 \mathrm{~Hz}, 2 \mathrm{H}), \delta 7.57(\mathrm{dd}, J=8.0,6.6 \mathrm{~Hz}, 2 \mathrm{H}), \delta$
$7.42(\mathrm{~d}, J=8.0 \mathrm{~Hz}, 2 \mathrm{H}), \delta 7.36(\mathrm{dd}, J=8.2 \mathrm{~Hz}, 2 \mathrm{H}), \delta 7.27(\mathrm{~d}, J=$ $7.8 \mathrm{~Hz}, 2 \mathrm{H}), \delta 7.21(\mathrm{~d}, J=8.2 \mathrm{~Hz}, 2 \mathrm{H}), \delta 3.67(\mathrm{~s}, 2 \mathrm{H}), \delta 2.48(\mathrm{~s}, 3 \mathrm{H}), \delta 2.01(\mathrm{~s}, 3 \mathrm{H}), \delta 0.62(\mathrm{~s}$, $3 \mathrm{H}), \delta 0.62(\mathrm{~s}, 3 \mathrm{H}) ;{ }^{13} \mathrm{C}$ NMR $\left(126 \mathrm{MHz}, \mathrm{CDCl}_{3}\right) \delta 146.9,141.00,140.98,139.8,139.1,135.1$, $134.91,133.14,133.08,132.8,132.3,129.49,129.47,128.4,126.0,125.68,38.3,15.2,15.0$, - 
5.00, -5.03; ${ }^{29} \mathrm{Si}$ NMR $\left(60 \mathrm{MHz}, \mathrm{CDCl}_{3}\right) \delta-22.7,-22.8$. HRMS predicted for $\mathrm{C}_{27} \mathrm{H}_{28} \mathrm{Si}_{2} \mathrm{~S}_{2}$ (ASAP+): calcd $472.1171\left([\mathrm{M}]^{+}\right)$, observed $472.1183\left([\mathrm{M}]^{+}\right)$.

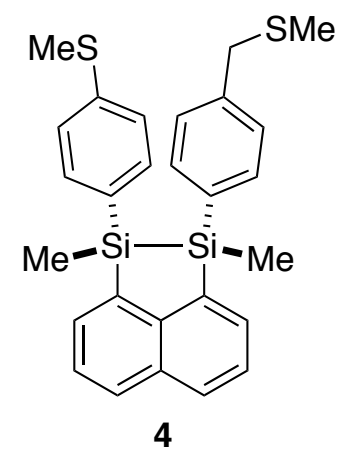

Clear oil. IR (thin film) 3045, 3029, 3006, 2955, 2919, 2851, 1578, 1483, 1438, 1426, 1382, 1368, 1309, 1249, 1229, 1218, 1156, 1101, 1078, 1017, $877,789,775,745,710,688,629,567,538,510,498,437 ;{ }^{1} \mathrm{H}$ NMR $(500$ $\left.\mathrm{MHz}, \mathrm{CDCl}_{3}\right) \delta 7.93(\mathrm{dt}, J=8.3,1.6 \mathrm{~Hz}, 2 \mathrm{H}), \delta 7.78(\mathrm{dd}, J=6.6,1.3 \mathrm{~Hz}$, $1 \mathrm{H}), \delta 7.74(\mathrm{dd}, J=6.7,1.3 \mathrm{~Hz}, 1 \mathrm{H}), \delta 7.54(\mathrm{dt}, J=8.2,6.5 \mathrm{~Hz}, 2 \mathrm{H}), \delta$ $7.24(\mathrm{~d}, J=8.2 \mathrm{~Hz}, 2 \mathrm{H}), \delta 7.18(\mathrm{~d}, J=8.2 \mathrm{~Hz}, 2 \mathrm{H}), \delta 7.11(\mathrm{~d}, J=7.7 \mathrm{~Hz}$, $2 \mathrm{H}), \delta 7.02(\mathrm{~d}, J=8.2 \mathrm{~Hz}, 2 \mathrm{H}), \delta 3.58(\mathrm{~s}, 2 \mathrm{H}), \delta 2.40(\mathrm{~s}, 3 \mathrm{H}), \delta 1.91(\mathrm{~s}$, $3 \mathrm{H}), \delta 0.75(\mathrm{~s}, 3 \mathrm{H}), \delta 0.73(\mathrm{~s}, 3 \mathrm{H}) ;{ }^{13} \mathrm{C} \mathrm{NMR}\left(126 \mathrm{MHz}, \mathrm{CDCl}_{3}\right) \delta$ 146.7, 141.1, 139.6, 138.9, 135.2, 135.0, 133.13, 133.07, 132.74, 131.7, 129.5, 128.3, 126.0, 125.4, 38.2, 15.2, 14.7, -4.68, $4.73 ;{ }^{29} \mathrm{Si} \mathrm{NMR}\left(60 \mathrm{MHz}, \mathrm{CDCl}_{3}\right) \delta-22.8,-22.9$. HRMS predicted for $\mathrm{C}_{27} \mathrm{H}_{28} \mathrm{Si}_{2} \mathrm{~S}_{2}$ (ASAP+): calcd $472.1171\left([\mathrm{M}]^{+}\right)$, observed $472.1166\left([\mathrm{M}]^{+}\right)$. 


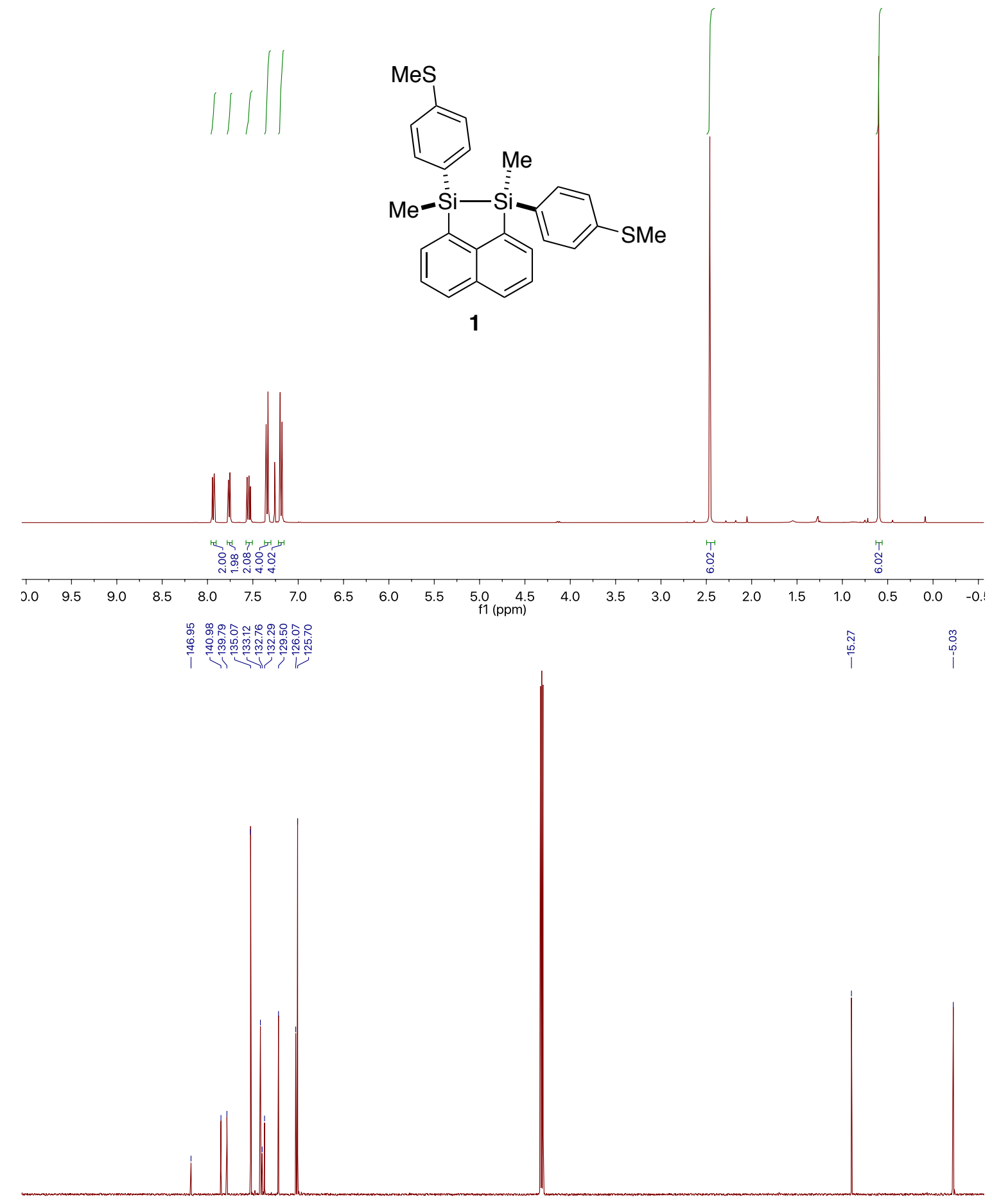

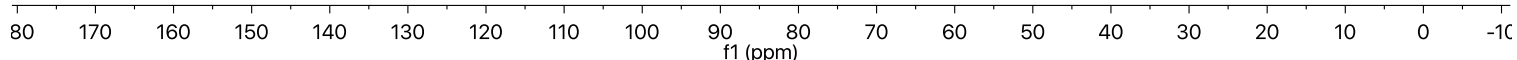



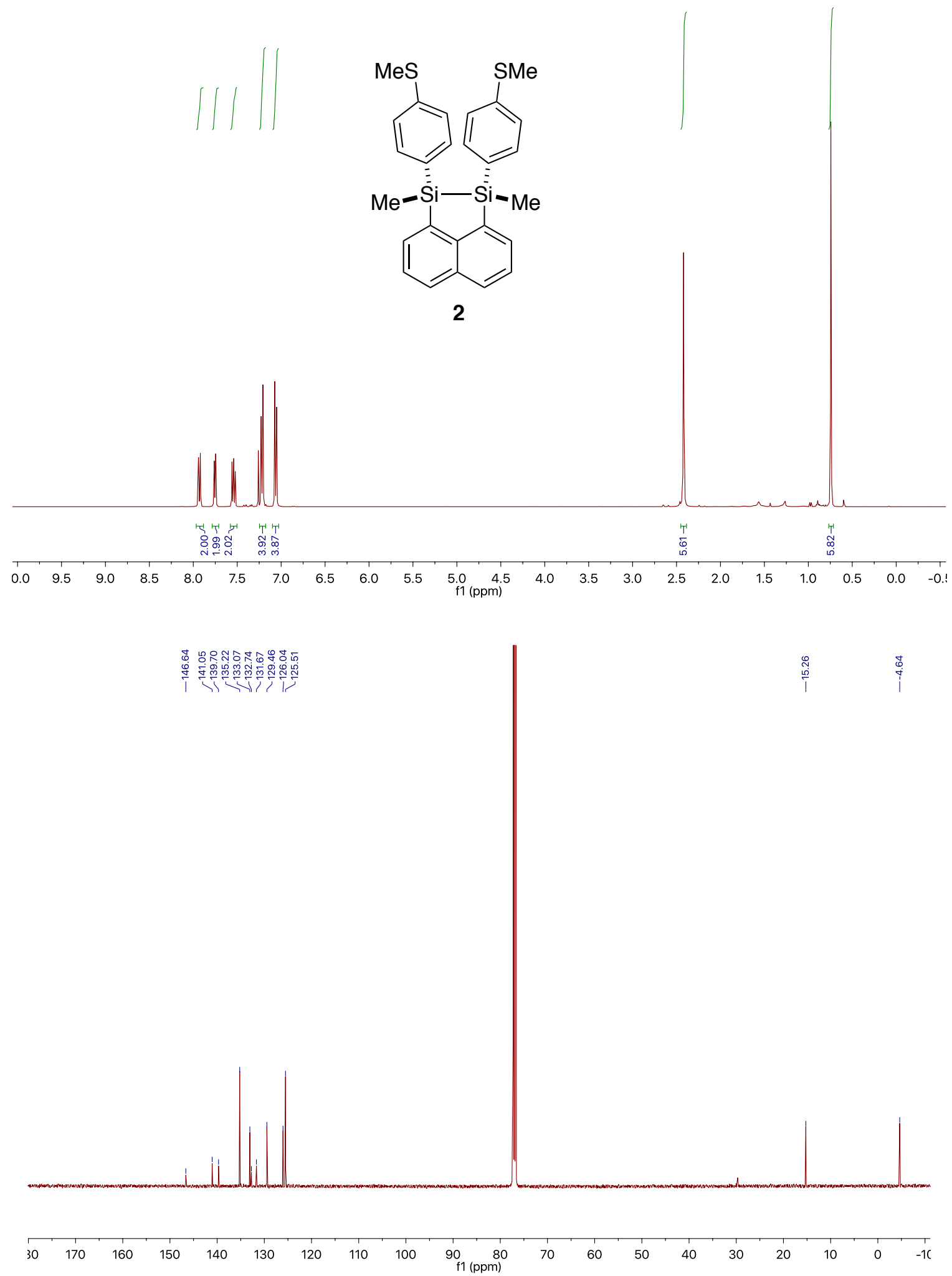

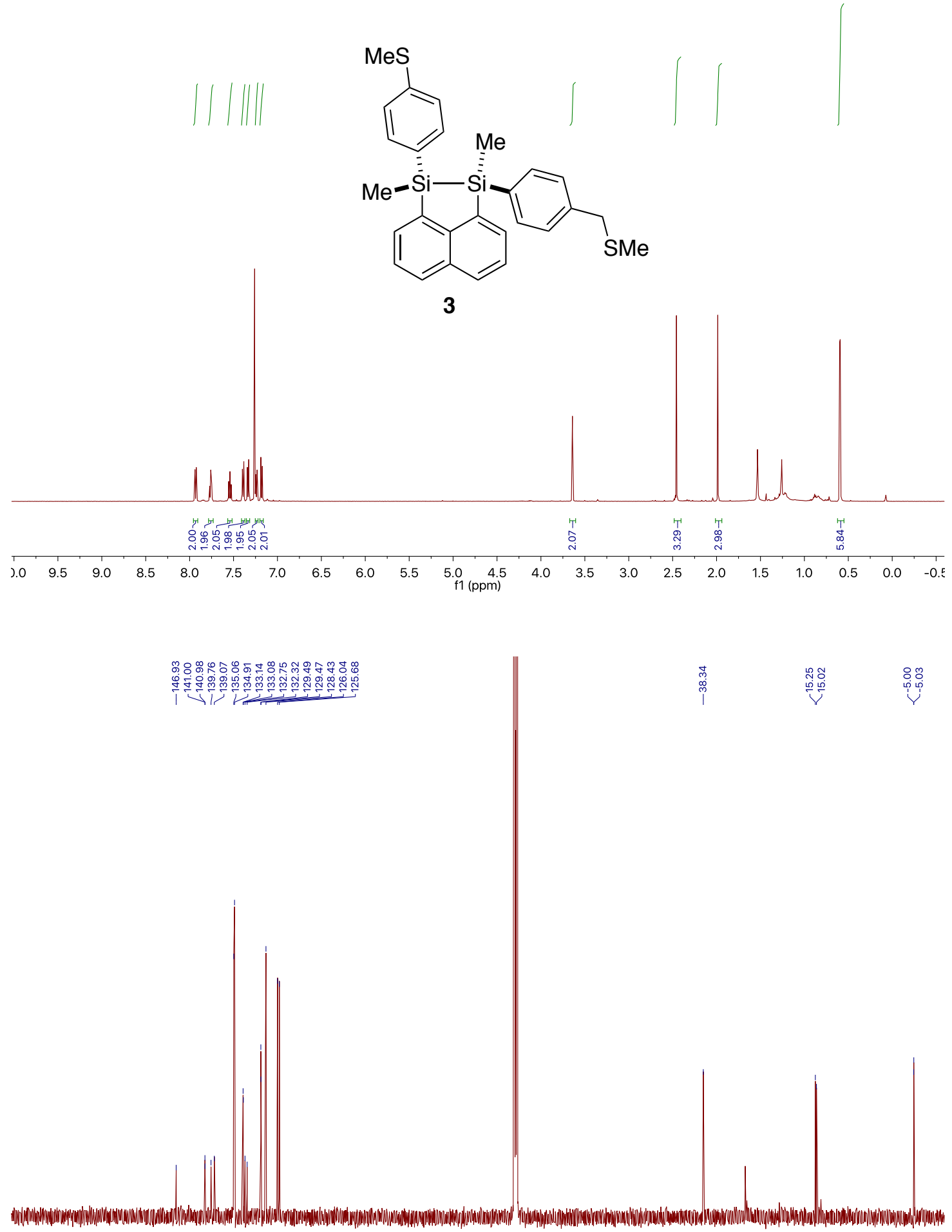

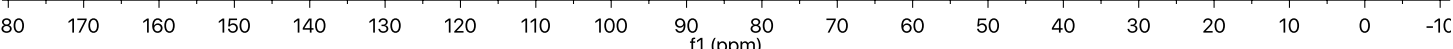



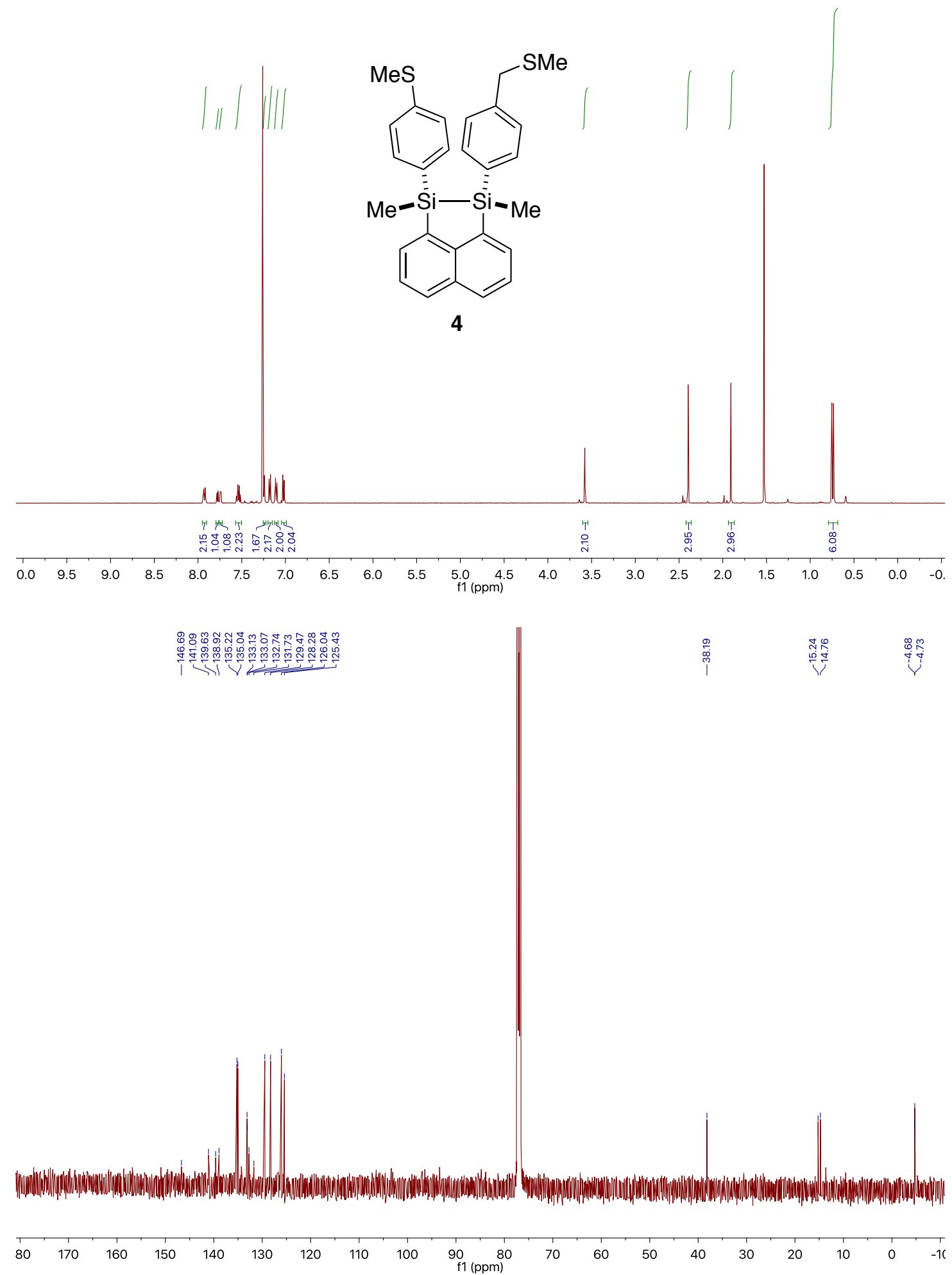
HPLC chromatograms of trans and cis bisthioanisole substituted 1,2-disilaacenaphthenes $\mathbf{1}$ and $\mathbf{2}$

Luna $3 \AA$ silica column, $15 \%$ dichloromethane in hexanes isocratic, $1 \mathrm{~mL} / \mathrm{min}$

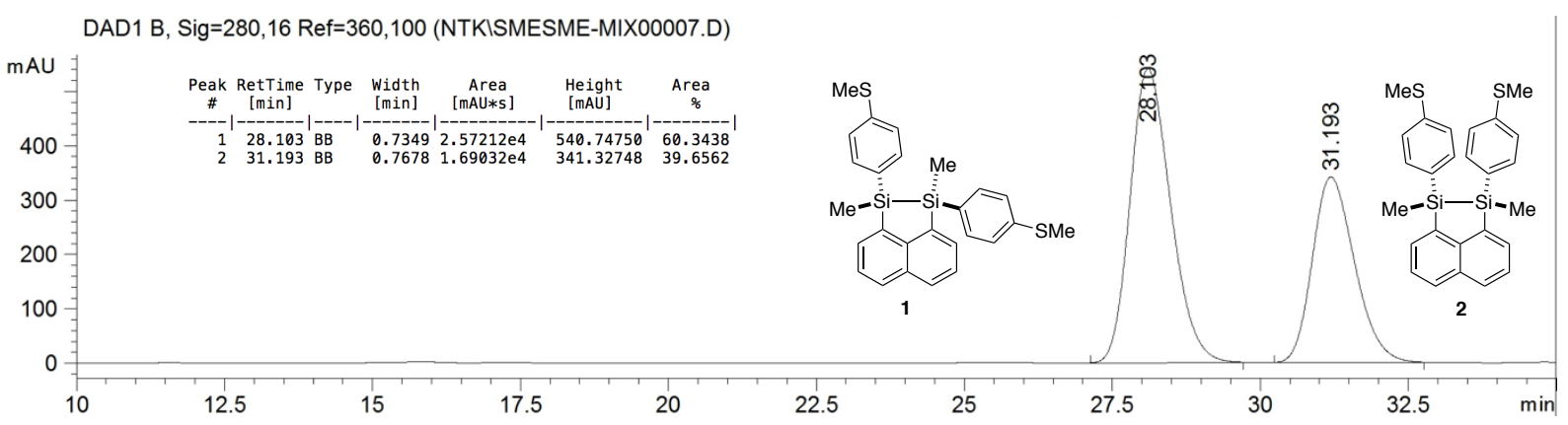

Chiralcel IB-3 column, 30 minutes, $0 \%$ to $15 \%$ dichloromethane in hexanes gradient, $1 \mathrm{~mL} / \mathrm{min}$

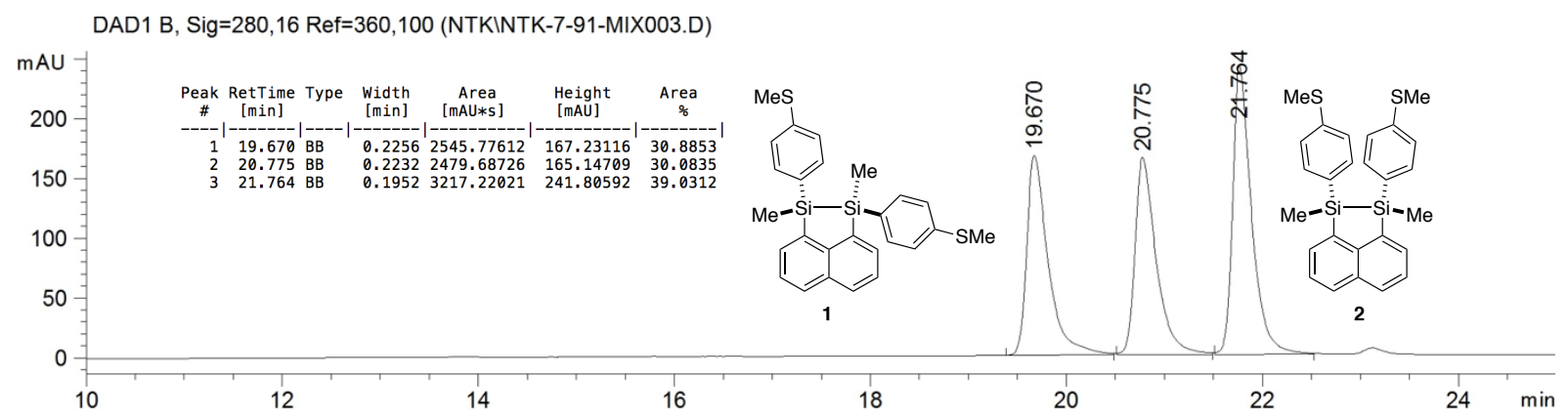

DAD1 B, Sig=280,16 Ref=360,100 (NTKINTK-7-91-TRANS4.D)

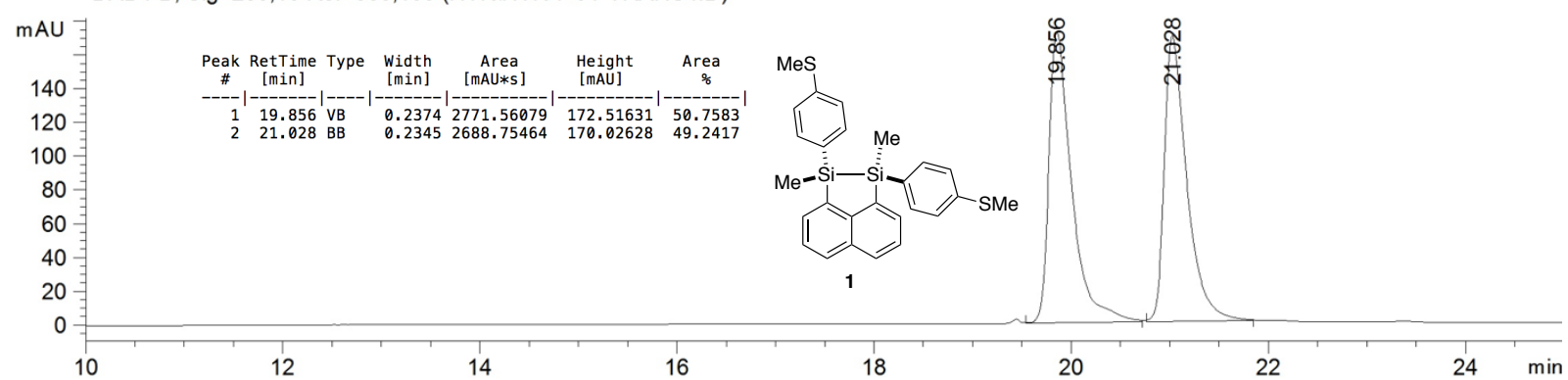

DAD1 B, Sig=280,16 Ref=360,100 (NTKINTK-7-91-CIS005.D)

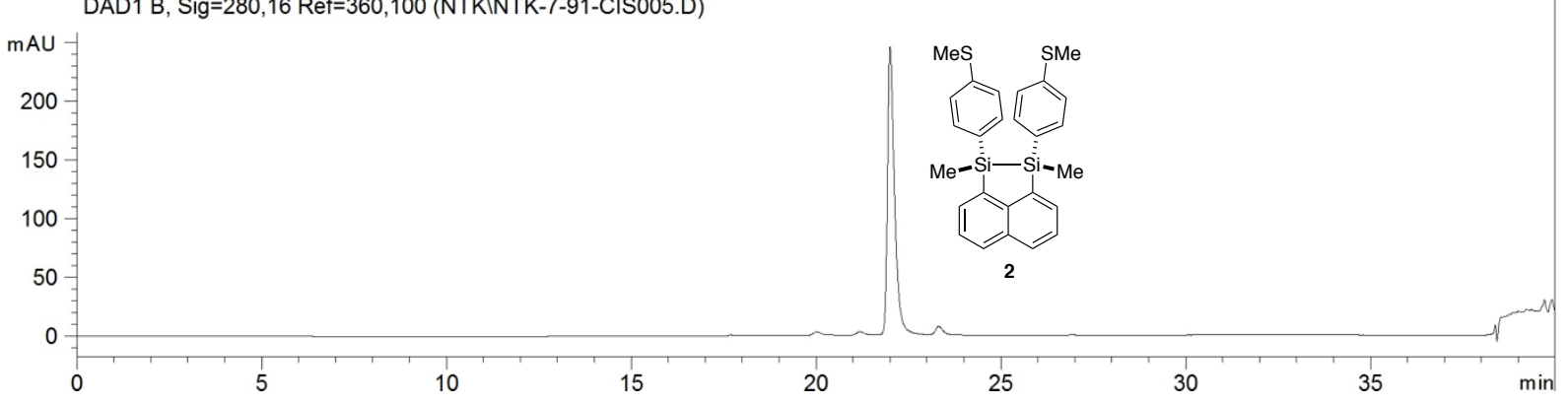


HPLC chromatograms of trans and cis asymmetric 1,2-disilaacenaphthenes 3 and $\mathbf{4}$

Luna $3 \AA$ silica column, $20 \%$ dichloromethane in hexanes isocratic, $1 \mathrm{~mL} / \mathrm{min}$

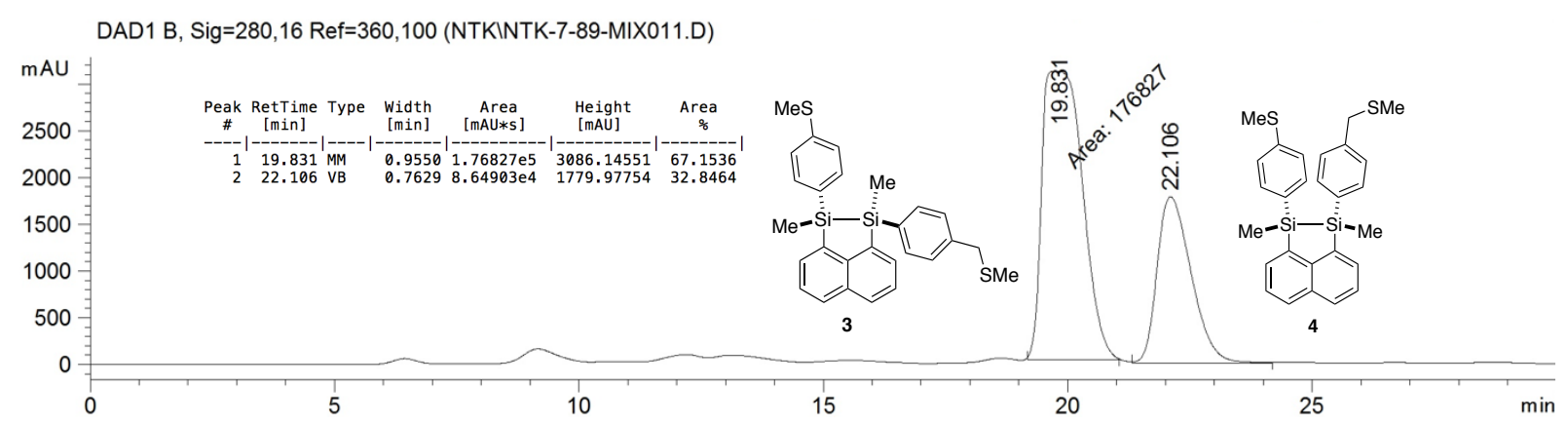

\section{References}

(1) Wakahara, T.; Kodama, R.; Akasaka, T.; Ando, W. Bull. Chem. Soc. Jpn., 1997, 70, 665.

(2) Kamenetska, M.; Koentopp, M.; Whalley, A. C.; Park, Y. S.; Steigerwald, M. L.; Nuckolls, C.; Hybertsen, M. S.; Venkataraman, L. Phys. Rev. Lett. 2009, 102, 126803. 